\title{
Audit picks a bone with US relics office
}

\section{Congressional watchdog unearths shortcomings at agency in charge of repatriating ancient tribal remains.}

To scientists, ancient human bones and artefacts from Native American burial sites can offer a unique window onto history. But to some modern Native American tribes, allowing researchers to study these remains amounts to desecration. Long-standing tensions between the two groups were meant to be eased by the Native American Graves Protection and Repatriation Act (NAGPRA) of 1990, which allows tribes to reclaim many remains held in museum collections.

But the first official audit of the government agency that administers NAGPRA portrays a troubled organization that has failed to serve tribes well, and does not always give a fair hearing to scientists' claims. The final report, from the US Government Accountability Office (GAO), is expected by autumn, but Nature has obtained a draft that is currently under review. Both the GAO and the NAGPRA office in Washington DC declined to comment on the draft.

The act created a system in which museums, universities or federal agencies that hold ancient skeletal remains and associated funerary objects had to file inventories of such items by 1995 with the NAGPRA office, part of the US Department of the Interior. Any tribe could reclaim items that were shown to be culturally affiliated with it, while the remainder could be kept by institutions for further study. The GAO report says that under the NAGPRA, 142,186 specimens have been repatriated from 209,626 publicly disclosed items. These constitute $55 \%$ of the human remains and $69 \%$ of the associated funerary objects that were inventoried.

But determinations of cultural affiliation often prove to be ambiguous and contentious, as in the Kennewick man dispute, in which the US courts ruled in 2004 that scientists could retain a 9,000-year-old skeleton from Washington state. In May this year, tensions ratcheted up when the Department of the Interior unveiled a federal rule that could allow tribes to claim thousands more artefacts - with no cultural connection - if they had been found near tribal lands (see Nature 464, 662; 2010). Some scientists are already considering legal challenges to prevent these repatriations.

Yet as NAGPRA administrators struggle

to manage these disputes, the GAO report finds that the NAGPRA office - which has an annual budget of US\$1 million - is beset by problems including inadequate resources and poor record-keeping. These can delay repatriations and make it harder to reach decisions on contentious cases. "We have heard for years the NAGPRA office statistics were often wrong, but it is like pulling teeth to get them corrected,"

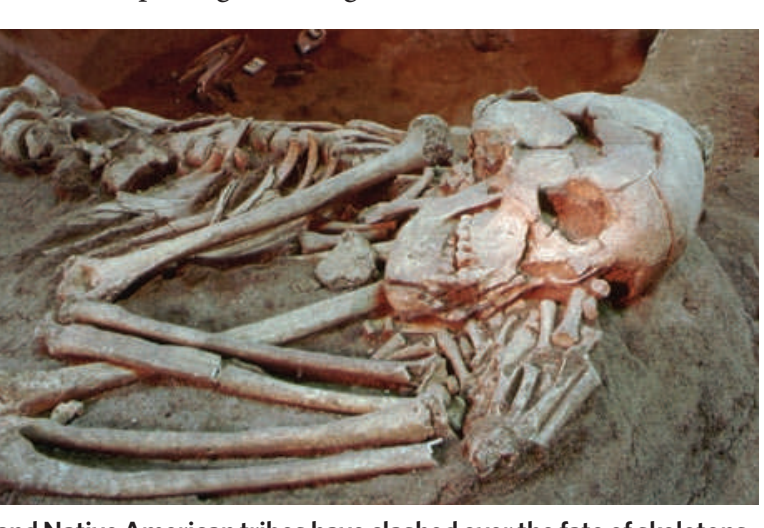
State University in East Lansing, who helped create the act.

The report notes that NAGPRA officials defended such practices, saying that one official "believed that the Review Committee had become too weighted toward the interests of the museum and scientific communities." The NAGPRA office did not respond to questions from Nature on the matter.

\section{'Crazy and wrong'}

The audit also assessed how well eight federal agencies complied with the act. It found that three the US Army Corps of Engineers, the US Forest Service and the US National Park Service - were highly compliant. But there was less confidence in the remaining agencies, including the US Fish and Wildlife Service and the Tennessee Valley Authority, which operates hydroelectric power plants built in the 1930s, when

says Vincas Steponaitis, an archaeologist at the University of North Carolina at Chapel Hill, who in 2004-08 served on the NAGPRA review committee that oversees repatriations and adjudicates on ownership disputes.

The report also suggests that the NAGPRA office has manipulated the make-up of the seven-person committee, weakening scientists' voices in its decisions. The committee comprises three tribal members, three representatives of scientific organizations and an independent member agreed on by the others. Nominations for candidates are sent to the NAGPRA office, which makes
ndation to the secretary of the interior department.

But the GAO audit says that the NAGPRA office inadequately screened these nominees, and passed over nominations for scientific representatives in favour of its own candidates. It also says that the office used "questionable efforts to recruit members" of its own liking, including selecting a candidate six months after the nomination deadline and resurrecting a seven-year-old nomination to fill one of the science seats. "It was clear NAGPRA staff wanted to prevent strong advocates for science as professional organization representatives," says about 8,400 ancient remains were unearthed.

The report says that the authority failed to publish notices to alert tribes to 337 "culturally affiliated human remains" that could have been repatriated. But the authority denies the charge, and has provided Nature with documents indicating that cultural affiliation was not confirmed, and that notices were sent to five tribes, who did not respond.

A table in the report states that the Fish and Wildlife Service did not notify tribes about 100 culturally affiliated skeletons that were uncovered in Louisiana in the 1930s when the Natchitoches National Fish Hatchery was built. But wildlife-service researchers and tribe representatives say that these skeletons were not removed from the site. The GAO report's suggestion otherwise is "crazy; it's wrong”, says Bobby Gonzalez, NAGPRA officer for the Caddo Nation, now of Binger, Oklahoma. Archaeologists add that such mistakes are indicative of the NAGPRA office's poor record-keeping.

"The GAO findings are examples of everything I've heard about for a decade," says Goldstein. She and others say that they hope the report will lead to a shake-up at the NAGPRA office to ensure that rules on Native American artefacts are followed properly.

Rex Dalton 